Reprinted from "The Proceedings of the Indian Academy of Sciences",

Vol. XXXVI, No. 1, Sec. A, 1952

\title{
PRELIMINARY OBSERVATIONS ON THE TEMPERATURE GRADIENTS AND LIGHT PENETRATION IN THE UPPER 200 FEET OF WATER OF THE BAY OF BENGAL*
}

\author{
By RAgHU PRASAD \\ (Central Marine Fisheries Research Station, Mandapam Camp) \\ Received December 13, 1951 \\ (Communicated by Dr. N. K. Panikkar, F.A.sc.)
}

INTRODUCTION

IT is a common experience in the sea in low latitudes that insolation warms the upper layers, and that below a depth of about 100 meters there is usually a rapid fall in temperature. This lower layer of water with rapidly increasing density is known as the thermocline or discontinuity layer. The presence or otherwise of a thermocline has far reaching effects on the organic production and the distribution of planktonic organisms.

The earliest account of the temperatures at different levels of the Indian Ocean was given by Carpenter (i887) in which he gives the results of his observations in the Bay of Bengal. Schott (1902), Krümmel (1911), Matthews (1926) and Sewell (1932) have added to our understanding of the temperature gradients in the waters surrounding India. Still our present day knowledge on this subject is meagre.

Many devices have been invented for obtaining the temperature as a continuous function of depth but the bathythermograph designed by Spilhaus (1938) and later-considerably modified by him, has overcome many of the difficulties that rendered previous designs ineffective. With the bathythermograph (Thermarine Recorder Model FA-190011) available at the Central Marine Fisheries Research Station it was decided to make observations on the temperature gradients whenever possible. Although the aim is to obtain a complete picture of the kaleidoscopic changes in the hydrological conditions throughout the year, owing to many difficulties it will only be possible at this stage to make intermittent observations and try to complete the picture in course of time.

* Published with the permission of the Chief Research Officer, Central Marine Fisheries Research Station, Mandapam Camp, South India. 
The following observations were made during a cruise from Trincomali to Madras, Calcutta, back to Madras and then to Mandapam. During the cruise cbservations on temperature gradients were made at 22 stations and water samples were collected at these stations as well as from another five stations (Fig. 1). The $\mathrm{pH}$ of these samples was determined on board the ship using Bromthymol blue as the indicator but the determination of salinity had to wait until the samples were brought back to the laboratory. The

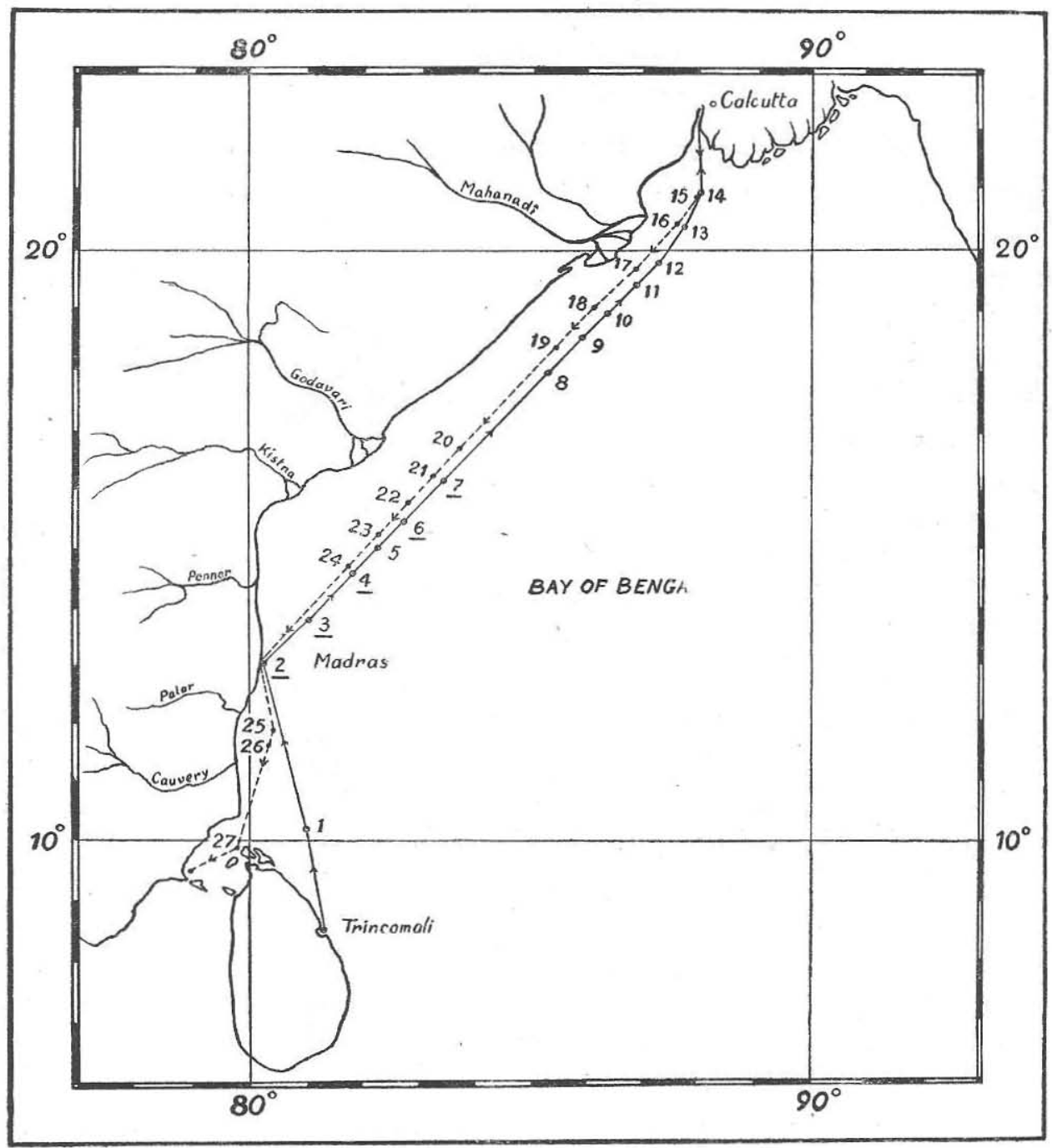

FIG. 1. Shows the stations at which observations were made. Numbers underlined indicate stations where bathythermograph readings were not taken. 
salinity was estimated by the standard chlorinity titration method. Information such as the exact position, atmospheric temperature, barometric pressure, colour of water, nature of sea, depth and nature of bottom, direction and force of wind at the tims of observation was alss recorded in log sheets. At stations covered during day time, the penetration of sunlight was measured with the aid of a Secchi disc.

It may be mentioned here that the observations presented below are not to be regarded in any sense as a complete survey, but represent the first step in collecting adequate data for an understanding of the hydrological conditions of the water masses surrounding our peninsula.

In embarking on investigations of this kind it is necessary to call upon many persons for assistance and it gives me great pleasure to ackrowledge the help received. This investigation, carried out on board I.N.S. Eelhl, was made possible by the willing co-cperation of the Navy and the Central Marine Fisheries Research Station. First and foremost amongst these, I wish to mention Rear-Admiral G. Barnard, Rear-Adimiral Commanding the Indian Naval Squadron and Captain Chatterji to whom I tender my gratitude and appreciation. To the Naval Personnel who helped me in managing the bathythermograph and the Secchi disc I offer my sincere thanks.

\section{Distribution of TEMPERATURE IN THE UPPER 200 FeEt of W}

Carpenter (1887) showed that from the surface to a depth of nearly 20 fathoms the temperature shows only little change but below this lies a zone extending downwards for more than the next hundred fathoms in which the temperature falls rapidly. Schott (1902) concluded from the data he had at his disposal that in the Indian Ocean the discontinuity layer lies at a depth below the surface which is intermediate between that found in the Atlantic and Pacific Oceans, i.e., between 90 and 140 meters. He attributes the presence of this zone partly to the alternating effects of the seasons and partly also to the effect of lateral movements of the upper stratum which cause a thinning of the surface currents resulting in the deep lying colder and more saline water approaching the surface. Thus during hot weather the surface water becomes condensed ard has a raised temperature but during the cold season this water cools and sinks down to a depth of 91 to 137 meters. Krümmel (1911), however, points out that true discontinuity layers in the other seas occur at a level that is only a few meters, 15 to 20 meters, below the surface which is caused by the heating up of the uppermost levels in summer and refuses to believe that this sudden change in temperature at depths as great as 100 meters can in any way be due to the heating up and evaporation of the surface water, $\mathrm{He}$ is of opinion that a sharply defined 
thermocline is caused either due to the ascending movements of deep strata that carry cold water towards the upper levels, which have been warmed by the sun, or to horizontal movement of large masses of water due to the surface currents, the warm upper layer thus becoming sharply separated from the deeper colder water. Sewell (1932) suggests that in the Bay of Bengal the discontinuity layer may be produced in yet another manner, at least at certain seasons of the year, by the dilution of the surface water by rain or river water and thus by virtue of its reduced salinity and specific gravity it fioats on the top of more saline water preventing usual convection currents setting up and restricting warming up by insolation to the upper stratum resulting in the formation of a discontinuity zone where two layers of unequal salinity meet. According to him the average temperature of the surface water, as calculated from all observations is $28.31^{\circ} \mathrm{C}$. and, as a rule, there is only very little change in the upper 25 fathoms at which depth the average temperature is $26 \cdot 75^{\circ} \mathrm{C}$.

Sewell, op. cit., has constructed a graph showing the upper and lower limits of the discontinuity zone throughout the year for the Bay of Bengal and the Andaman Sea. He also points out, however, that no data were available for the months of either August or September. The upper level, according to Sewell, for August is 40 to 50 fathoms and the lower limits for the same month being from 78 to 90 fathoms. But the observations recorded here for the month of August (August 9 to 29) show the existence of definite thermoclines at several places in the Bay of Bengal at comparatively low levels.

Schott (1902) has suggested that the thermocline should be defined as one in which the temperature changes by not less than $2^{\circ} \mathrm{C}$. $\left(3 \cdot 6^{\circ} \mathrm{F}\right.$.) in 25 meters vertically. According to this definttion it will be noticed that there are well marked thermoclines developed within the upper 200 feet at several places during August (stations 8 to 11, 17 to 20,25 and 26). The depths at which thermoclines develop vary from place to place and also from time to time. It is seen from Figs. 3 and 4 that at the stations 8 to 11 thermoclines developed approximately at $65,65,70$ and 75 feet respectively, whereas at stations 17 to 20,25 and 26 the thermocline was at $130,90,35,60,120$ and 110 feet respectively (Figs. 8, 9, 11 and 12). It may be added here that at stations 12 to 16 (Fig. 1) one would not normally expect definite thermoclines in the upper 200 feet of water as there is likely to be considerable mixing up of water in the upper layers owing to the influx of large quantities of water brought down by the Ganges and Mahanadi (Figs. 5, 6, 7 and 8). In this connection it may be pointed out that the depths at which thermoclines developed at stations 8 to 11 gradually increase from 65 to 75 feet which may 


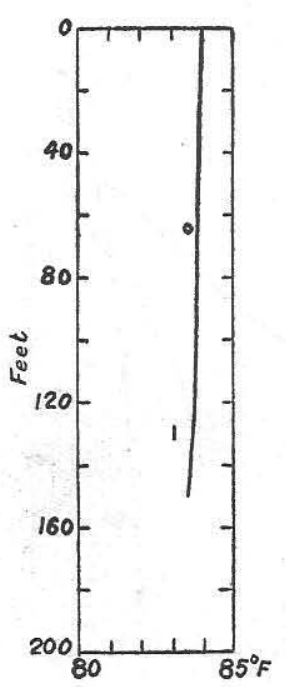

Fig. 2.

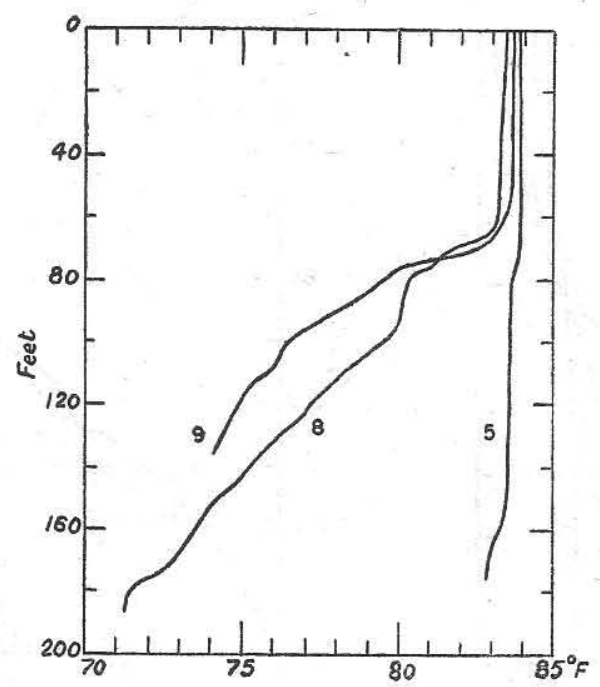

Fig. 3

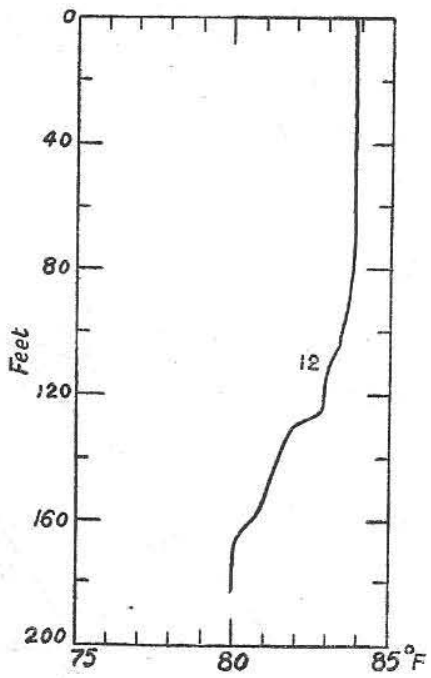

Fig. 5

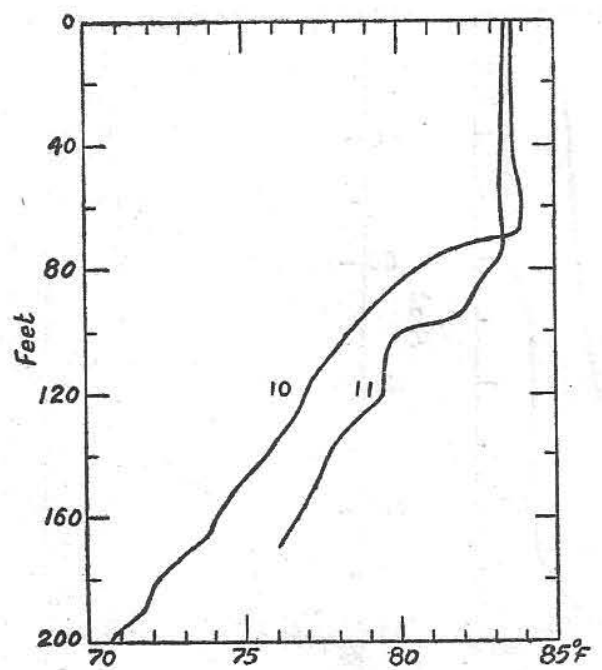

Fig. 4

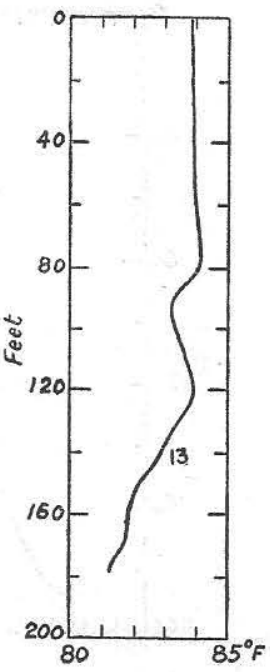

Fig. 6

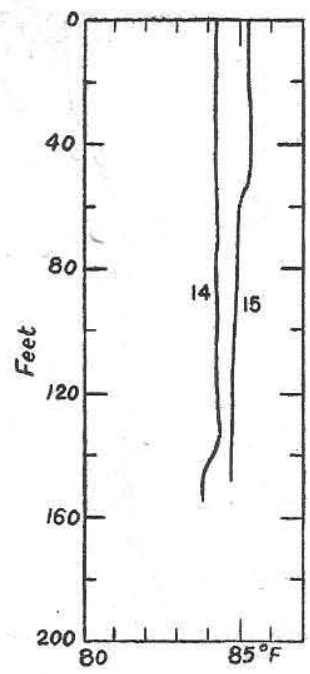

Fig.7

Figs. 2-7. Show the distribution of temperature in different depths at ten stations. Number against each line represents station number.

indicate the spreading of a tongue of less saline and lighter water which, as is to be expected, thins out gradually. It is likely that thermoclines are developed at the stations mentioned above at the places where the two strata of 


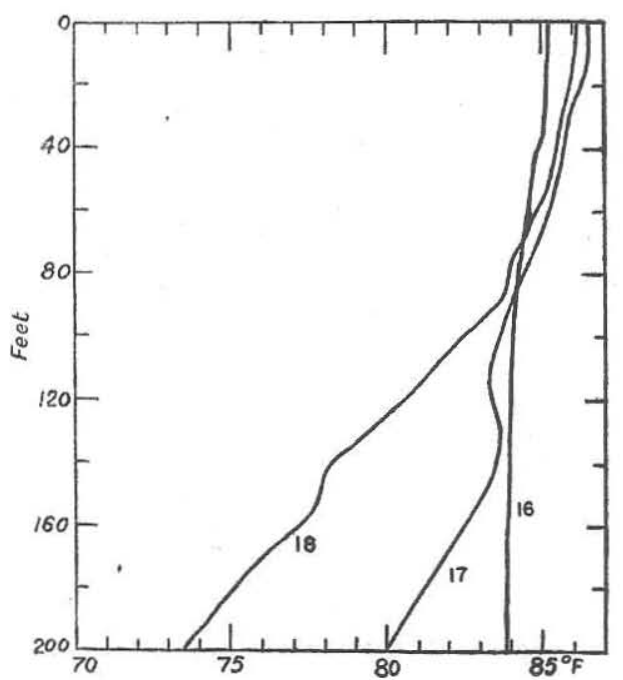

Fig. 8

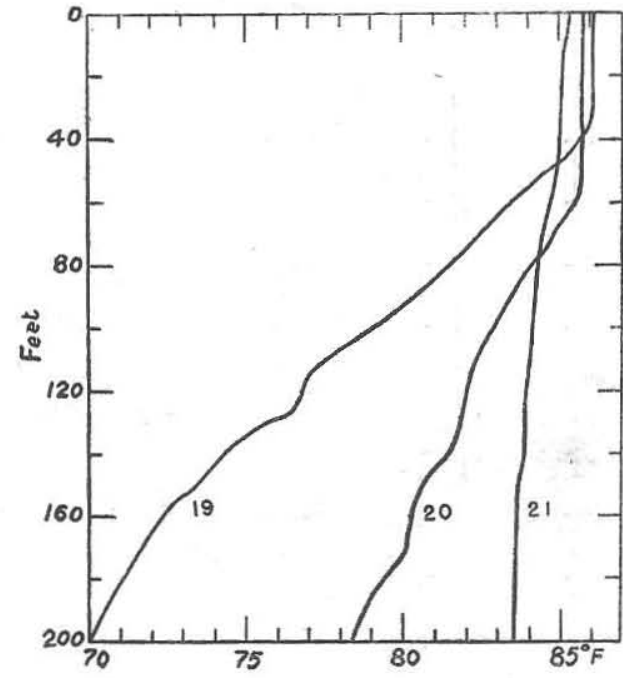

Fig. 9

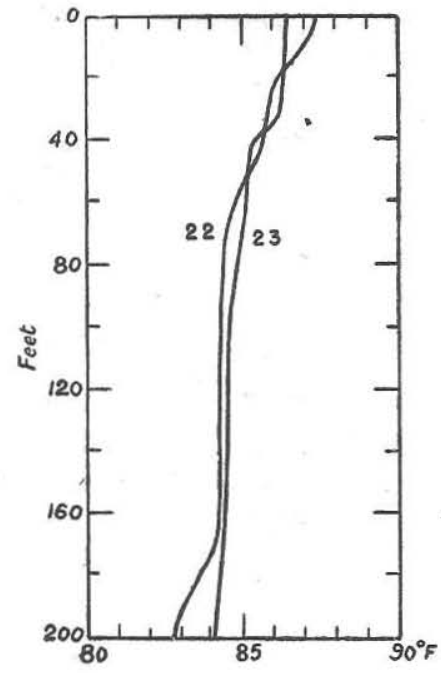

Fig. 10

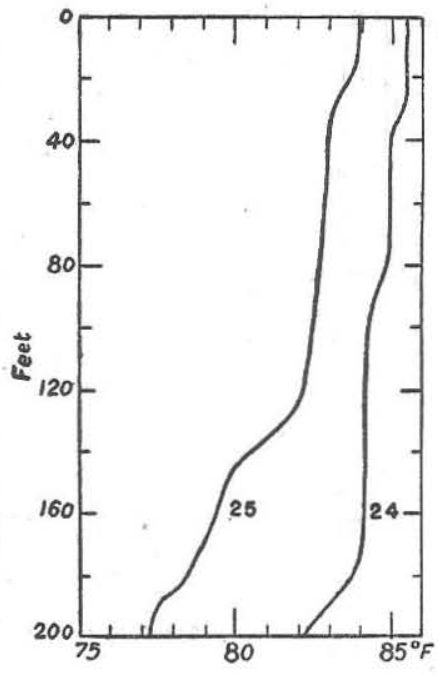

Fig.II

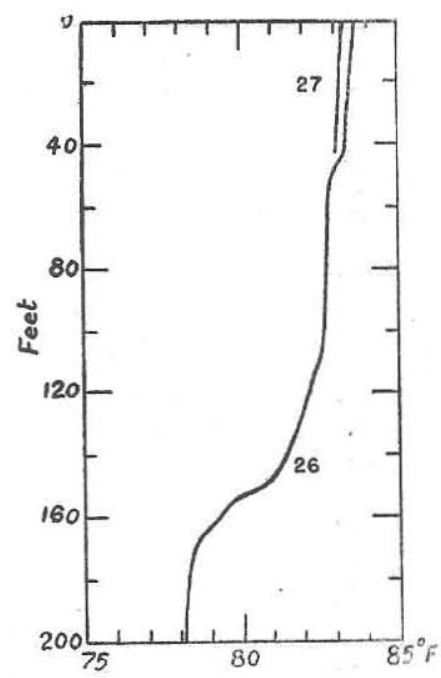

Fig. 12

Figs. 8-12. Distribution of temperature at different depths at twelve stations in the Bay of Bengal. Number against each line denotes station number.

water of different salinity meet, as suggested by Sewell, and it is probable that thermoclines might have existed at deeper layers as we approach the mouths of the rivers, Again the thermocline at station 17 was at 130 feet, 
the location of the station being near the mouth of Mahanadi, whereas as we move away from the river mouth it will be observed that the thermocline develops closer to the surface-90 and 35 feet at stations 18 and 19 respectively. Station 20 shows a thermocline at 60 feet while at the next four stations there are no thermoclines developed within the upper 200 feet (Figs. 9, 10 and 11). Thermoclines are developed at 120 and 110 feet at stations 25 and 26 respectively. The same explanation holds good for all these stations, i.e., those located just opposite river mouths (21 to 24) do not show thermoclines within the 200 feet and at those places where the influence of river water is only slightly felt the thermoclines develop comparatively near the surface. It is of interest to note here that at stations 8,10 , 18 and 19 the difference in the temperaturcs between the surface and at 200 feet is about the same as the maximum difference observed in the fluctuation of the surface temperature in any month. According to Sewell (1929) the extreme range of surface temperature, i.e., between the highest and the lowest recorded temperatures, in each month rises from $3.2^{\circ} \mathrm{C}$. in April to $6.45^{\circ} \mathrm{C}$. in December. The range in surface temperature recorded during this cruise is $4 \cdot 02^{\circ} \mathrm{C}$. $\left(c a_{i}, 7 \cdot 23^{\circ} \mathrm{F}\right.$.). Stations 8 to 11 and 18 to 20 show this or greater difference in temperature between the surface and at 200 feet (Figs. 3, 4, 8 and 9). This may mean that the changes in the surface temperature may be brought about by the mere upwelling of the subsurface water but whether this phenomenon actually happens and also whether this is one of the contributing factors it is difficult to say at present.

\section{Light Penetration}

Another factor which is most important for organic production is radiation. It not only directly controls the phytoplankton production but is important indirectly through its effect on temperature. The light that is effective for phytoplankton growth depends, of course, on the transparency of the water. The light falling on the sea is continuously changing with time and thus the depth of photosynthetic zone varies throughout the day with the intensity of illumination. The transparency of the water plays a leading part in controlling the depth of the photosynthetic zone and similarly the relative position of the thermocline and the euphotic zone is also of considerable importance in organic production.

Factors such as the presence of debris and plant cells in large quantities increase the turbidity. In certain cases plant cells themselves may become abundant to cause a significant decrease in transparency. The extent to which plant cells may cut off light is shown by Clarke (1946) in which he has given the relation between the Secchi disc measurements and the abund- 
TABLE I. Oceanographic data collected during the cruise

\begin{tabular}{|c|c|c|c|c|c|c|c|c|c|c|c|}
\hline \multirow{2}{*}{ Date } & \multirow{2}{*}{$\begin{array}{l}\text { Station } \\
\text { number }\end{array}$} & \multicolumn{2}{|c|}{ Position } & \multirow{2}{*}{$\begin{array}{l}\text { Time } \\
\text { Hrs. }\end{array}$} & \multirow{2}{*}{$\mid \begin{array}{c}\text { Surface } \\
\text { temp. }\end{array}$} & \multirow{2}{*}{$\begin{array}{c}\text { Atmospheric } \\
\text { temp. }{ }^{\circ} \mathrm{C} .\end{array}$} & \multirow{2}{*}{$\mathrm{p}_{2 /}^{\mathrm{H}}$} & \multirow{2}{*}{$\underset{\% \circ}{\text { Salinity }}$} & \multirow{2}{*}{$\sigma_{t}$} & \multirow{2}{*}{$\begin{array}{l}\text { Depth } \\
\text { (fm.) }\end{array}$} & \multirow{2}{*}{$\begin{array}{l}\text { Max. depth of } \\
\text { visibility of } \\
\text { Secchi disc. } \\
\text { (ft.) } 3 /\end{array}$} \\
\hline & & $\begin{array}{c}\text { N. } \\
\text { Latitude }\end{array}$ & $\begin{array}{c}\text { E. } \\
\text { Longitude }\end{array}$ & & & & & & & & \\
\hline & & & & - & & & & & & & \\
\hline $9-8-1950$ & 1 & $10^{\circ} 16^{\prime} 00^{\prime \prime}$ & $81^{\circ} 02^{\prime} 00^{\prime \prime}$ & $05 \quad 45$ & 28.47 & $29 \cdot 16$ & $8 \cdot 27$ & $33 \cdot 84$ & $21 \cdot 25$ & 1210 & 48 \\
\hline $10-8-1950$ & $2^{*}$ & $13^{\circ} 08^{\prime} 00^{\prime \prime}$ & $80^{\circ} 18^{\prime} 00^{\prime \prime}$ & 0600 & $26 \cdot 67$ & $25 \cdot 56$ & 8.07 & $34 \cdot 76$ & $22 \cdot 66$ & .. & .. \\
\hline do & $3^{*}$ & $13^{\circ} 48^{\prime} 00^{\prime \prime}$ & $81^{\circ} 01^{\prime} 00^{\prime \prime}$ & 1000 & $28 \cdot 33$ & $29 \cdot 44$ & $8 \cdot 27$ & $34 \cdot 04$ & $21 \cdot 58$ & $>1300$ & . \\
\hline do & $4^{*}$ & $14^{\circ} 37^{\prime} 00^{\prime \prime}$ & $81^{\circ} 50^{\prime} 00^{\prime \prime}$ & 1400 & $28 \cdot 33$ & $29 \cdot 72$ & $8 \cdot 27$ & $34 \cdot 01$ & $21 \cdot 56$ & $>1300$ & . \\
\hline do & 5 & $15^{\circ} 06^{\prime} 00^{\prime \prime}$ & $82^{\circ} 20^{\prime} 00^{\prime \prime}$ & 1630 & $28 \cdot 75$ & 30.00 & $8 \cdot 37$ & $33 \cdot 73$ & $21 \cdot 21$ & $>1300$ & $\ddot{62}$ \\
\hline do & $6^{*}$ & $15^{\circ} 24^{\prime} 00^{\prime \prime}$ & $82^{\circ} 37^{\prime} 60^{\prime \prime}$ & 1800 & $28 \cdot 33$ & $28 \cdot 61$ & 8.37 & $33 \cdot 93$ & $21 \cdot 50$ & $>1300$ & .. \\
\hline do & 7 * & $16^{\circ} 11^{\prime} 00^{\prime \prime}$ & $83^{\circ} 24,00^{\prime \prime}$ & 2200 & 28.05 & 28.89 & $8 \cdot 17$ & $33 \cdot 94$ & $21 \cdot 60$ & $>1300$ & .. \\
\hline $11-8-1950$ & 8 & $18^{\circ} 01^{\prime} 00^{\prime \prime}$ & $82^{\circ} 16^{\prime} 30^{\prime \prime}$ & 0700 & $28 \cdot 47$ & $30 \cdot 00$ & $8 \cdot 38$ & $31 \cdot 29$ & 19.15 & $>1300$ & $\ddot{54}$ \\
\hline do & 9 & $18^{\circ} 37^{\prime} 30^{\prime \prime}$ & $85^{\circ} 56^{\prime} 00^{\prime \prime}$ & 1000 & $28 \cdot 61$ & 30.56 & $8 \cdot 28$ & 30.41 & $18 \cdot 44$ & 1233 & 48 \\
\hline do & 10 & $18^{\circ} 57^{\prime} 00^{\prime \prime}$ & $86^{\circ} 22^{\prime} 00^{\prime \prime}$ & 1300 & 28.61 & $29 \cdot 72$ & $8 \cdot 28$ & $29 \cdot 85$ & $18 \cdot 03$ & 1233 & 60 \\
\hline do & 11 & $18^{\circ} 25^{\prime} 00^{\prime \prime}$ & $96^{\circ} 46^{\prime} 00^{\prime \prime}$ & 1600 & 28.75 & $30 \cdot 27$ & $8 \cdot 28$ & $31 \cdot 19$ & $19 \cdot 32$ & 790 & 49 \\
\hline do & 12 & $19^{\circ} 53^{\prime} 30^{\prime \prime}$ & $87^{\circ} 12^{\prime} 30^{\prime}$ & 1900 & $28 \cdot 75$ & $28 \cdot 33$ & $7 \cdot 78$ & $30 \cdot 41$ & $19 \cdot 73$ & 493 & .. \\
\hline do & 13 & $20^{\circ} 25^{\prime} 20^{\prime \prime}$ & $87^{\circ} 38^{\prime} 30^{\prime \prime}$ & 2200 & 28.75 & $28 \cdot 61$ & $8 \cdot 18$ & 30.01 & $18 \cdot 43$ & 47 & $\ddot{. .}$ \\
\hline $12-8-1950$ & 14 & $20^{\circ} 55^{\prime} 00^{\prime \prime}$ & $88^{\circ} 02^{\prime} 00^{\prime \prime}$ & 0135 & 29.02 & $28 \cdot 33$ & $8 \cdot 38$ & $31 \cdot 29$ & $19 \cdot 30$ & 30 & .. \\
\hline $22-8-1950$ & 15 & $20^{\circ} 54^{\prime} 00^{\prime \prime}$ & $88^{\circ} 00^{\prime} 01^{\prime \prime}$ & 0711 & 29.58 & $29 \cdot 16$ & $8 \cdot 38$ & $28 \cdot 93$ & $17 \cdot 35$ & 26 & 14 \\
\hline do & 16 & $20^{\circ} 27^{\prime} 00^{\prime \prime}$ & $87^{\circ} 33^{\prime} 00^{\prime \prime}$ & 1000 & $29 \cdot 58$ & 30.56 & $8 \cdot 38$ & $29 \cdot 76$ & 17.97 & 38 & 36 \\
\hline do & 17 & $19^{\circ} 47^{\prime} 30^{\prime \prime}$ & $86^{\circ} 52^{\prime} 00^{\prime \prime}$ & 1400 & $30 \cdot 27$ & $31 \cdot 11$ & $8 \cdot 38$ & $30 \cdot 80$ & $18 \cdot 51$ & 483 & 36 \\
\hline do & 18 & $19^{\circ} 08^{\prime} 00^{\prime \prime}$ & $86^{\circ} 03^{\prime} 30^{\prime \prime}$ & $180 \mathrm{C}$ & $30 \cdot 14$ & 30.84 & $8 \cdot 38$ & $31 \cdot 44$ & 19.03 & 1182 & $\ldots$ \\
\hline do & 19 & $18^{\circ} 27^{\prime} 30^{\prime \prime}$ & $85^{\circ} 22^{\prime} 00^{\prime \prime}$ & 2200 & $30 \cdot 14$ & $28 \cdot 89$ & $8 \cdot 18$ & $31 \cdot 39$ & $19 \cdot 00$ & 1180 & .. \\
\hline $23-8-1950$ & 20 & $16^{\circ} 44^{\prime} 00^{\prime \prime}$ & $83^{\circ} 41^{\prime} 00^{\prime \prime}$ & 0700 & $29 \cdot 86$ & $28 \cdot 33$ & $8 \cdot 37$ & $33 \cdot 27$ & $20 \cdot 49$ & $>1300$ & 33 \\
\hline do & 21 & $16^{\circ} 15^{\prime} 00^{\prime \prime}$ & $83^{\circ} 12^{\prime} 00^{\prime \prime}$ & 1030 & 29.58 & $29 \cdot 16$ & $8 \cdot 37$ & $33 \cdot 61$ & $20 \cdot 85$ & $>1300$ & 78 \\
\hline do & 22 & $15^{\circ} 4500^{\prime \prime}$ & $82^{\circ} 53^{\prime} 00^{\prime \prime}$ & 1400 & 30.69 & 30.00 & $8 \cdot 37$ & $33 \cdot 64$ & $20 \cdot 49$ & 1185 & 78 \\
\hline do & 23 & $15^{\circ} 13^{\prime} 00^{\prime \prime}$ & $82^{\circ} 19^{\prime} 00^{\prime \prime}$ & 1800 & $30 \cdot 27$ & 28.89 & 8.37 & $33 \cdot 04$ & $20 \cdot 19$ & 1182 & .. \\
\hline do & 24 & $14^{\circ} 39^{\prime} 00^{\prime \prime}$ & $81^{\circ} 46^{\prime} 00^{\prime \prime}$ & 2200 & $29 \cdot 72$ & $29 \cdot 05$ & $8 \cdot 37$ & $33 \cdot 15$ & $20 \cdot 46$ & $>1300$ & .. \\
\hline $28-8-1950$ & 25 & $11^{\prime} 49^{\prime} 30^{\prime \prime}$ & $80^{\circ} 27^{\prime} 00^{\prime \prime}$ & 1720 & $28 \cdot 75$ & $27 \cdot 78$ & $8 \cdot 27$ & $34 \cdot 37$ & $21 \cdot 70$ & $>\mathrm{I} 300$ &. \\
\hline do & 26 & $11^{\circ} 42^{\prime} 00^{\prime \prime}$ & $80^{\circ} 22^{\prime} 00^{\prime \prime}$ & 1830 & $28 \cdot 61$ & 28.89 & $8 \cdot 27$ & $33 \cdot 93$ & $21 \cdot 41$ & $>1300$ & .. \\
\hline $29-8-1950$ & 27 & $09^{\circ} 52^{\prime} 00^{\prime \prime}$ & $79^{\circ} 55^{\prime} 00^{\prime \prime}$ & 0630 & $28 \cdot 47$ & $26 \cdot 67$ & $8 \cdot 37$ & $35 \cdot 10$ & $22 \cdot 41$ & 7 & . \\
\hline
\end{tabular}

* Stations marked with an asterisk indicate those at which water samples alone were collected.

1/ Readings were recorded in degrees Fahrenheit and have been converted to the Centigrade scale subsequently.

$2 /$ Corrected for the salt error of the indicator.

3 Average of depths at which the disc disappears and at which it appears. 
ance of phytoplankton. In all cases in which plant pigments exceeded 40,000 Harvey units per $m^{3}$ the Secchi disc depth was found to be reduced to 8 meters or less.

In order to get an idea of the penetration of light in the Bay of Bengal limits of visibility tests were conducted with the aid of the Secchi disc. It will be noticed from Table I that the depth varies from 33 to 78 feet except at station 15 . This station, as will be seen from Fig. 1 is located very close to the mouths of the Ganges and due to the influx of large quantities of mudlaiden water from the river, the transparency of water was reduced. Consequently the Secchi disc reading was only 14 feet. Owing to lack of facilities it was not possible to make plankton collections at any of these stations and hence the organic production in the euphotic zone could not be estimated.

Carpenter, A.

Clarke, G. L.

Krümmel, $\mathrm{O}$.

Mat thews, D. J.

Schott, G.

Sewell, R. B. S.

Spilhaus, A. F.

\section{LiteratURE CiTED}

. " Natural History Notes from H.M.'s Indian Marine Survey Steamer Investigator No. 8. The mean temperature of the deep waters of the Bay of Bengal," Jour. Asiatic Soc. Bengal, 1987, 56, Pt. 2, 230-32.

. "Dynamics of production in a marine area," Ecological Monographs, 1946, 16, 321-35.

.. Handbuch der Ozeanographie, 1911, 2, Stuttgart, 764 pp.

.. "Physical oceanography. No. 7. The Percy Sladen Trust Expedition to the Indian Ocean in 1905," Trans. Linn. Soc. London, 1926, Ser. 2, 19, 169-205.

.. "Oceanographic und Maritime Meteorology. Wissenschaftliche Ergebnisse der Deutschen Tiefsee-Expedition auf dem Dampfer," Valdivia, 1898-99, 1902, 1.

.. "Geographic and oceanographic research in Indian waters. Part 5. Temperature and salinity of the surface waters of the Bay of Bengal and Andaman Sea, with reference to the Laccadive Sea," Mem. Asiatic Soc. Bengal, 1929,9 (5), 207-356.

. "Geographic and oceanographic research in Indian waters, Pt. 6. Temperature and salinity of the deeper waters of the Bay of Bengal and Andaman Sea," ibid., 1932, 9 (6), $357-424$.

. " A bathythermograph," Jour. Mar. Research, 1938, 1, 95-100. 